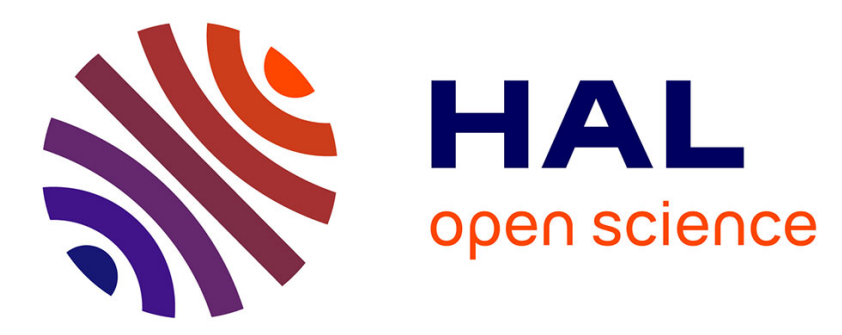

\title{
Facial dysplasia in wild forest olive baboons ( Papio anubis ) in Sebitoli, Kibale National Park, Uganda: Use of camera traps to detect health defects
}

Camille Lacroux, Nelson Guma, Sabrina Krief

\section{- To cite this version:}

Camille Lacroux, Nelson Guma, Sabrina Krief. Facial dysplasia in wild forest olive baboons ( Papio anubis ) in Sebitoli, Kibale National Park, Uganda: Use of camera traps to detect health defects. Journal of Medical Primatology, 2019, 48 (3), pp.143-153. 10.1111/jmp.12408 . mnhn-03256384

\section{HAL Id: mnhn-03256384}

\section{https://hal-mnhn.archives-ouvertes.fr/mnhn-03256384}

Submitted on 15 Jun 2021

HAL is a multi-disciplinary open access archive for the deposit and dissemination of scientific research documents, whether they are published or not. The documents may come from teaching and research institutions in France or abroad, or from public or private research centers.
L'archive ouverte pluridisciplinaire HAL, est destinée au dépôt et à la diffusion de documents scientifiques de niveau recherche, publiés ou non, émanant des établissements d'enseignement et de recherche français ou étrangers, des laboratoires publics ou privés. 
1 Facial dysplasia in wild forest olive baboons (Papio anubis) in Sebitoli,

2 Kibale National Park, Uganda: use of camera-traps to detect health defects

3

4

5

6

7

8

9

10

11

12

13

Running title: Malformations in wild olive baboons

Camille Lacroux ${ }^{\text {a,b }}$, Nelson Guma ${ }^{c}$, Sabrina Krief ${ }^{\text {a,b }}$

a UMR 7206 CNRS/MNHN/P7, Eco-anthropologie et ethnobiologie, Hommes, et Environnements, Museum national d'Histoire naturelle, Musée de l'Homme, 17 place du Trocadéro, 75116 Paris, France

${ }^{\mathrm{b}}$ Sebitoli Chimpanzee Project, Projet pour la Conservation des Grands Singes, Kibale National Park, Fort Portal, Uganda

${ }^{c}$ Uganda Wildlife Authority, Kibale National Park, Uganda

Corresponding author: Camille Lacroux

camille.lacroux@gmail.com

\section{Acknowledgement}

We are grateful to the Uganda Wildlife Authority, Uganda National Council for Science and Technology for permission to conduct research at Sebitoli. The Great Ape Conservation Project, the Fondation Ensemble, the Fondation pour la Nature et l'Homme, the Fondation Prince Albert II provided financial support for the research conducted at Sebitoli. We deeply thank JeanMichel Krief, co-director of Great Ape Conservation Project, the field assistants of the Sebitoli Chimpanzee Project Emmanuel Balinda, Deogratius Kiomuhangi, Joseph Alinaitwe, Ibrahim Nyakana, Wilson Muzahura, Edward Kalyegira, Nelson Tegume and Nelson Fawoh, the SCP coordinator, Robert Asyimwe, Robert Nyakahuma and Daniela Birungi. We thank Sarah Bortolamiol for her collaboration to organize spatial data. 
\# tables: 4

\# figures: 1

\section{Abstract}

Background: Primate populations are in decline, mainly affected by agriculture leading to habitat loss, fragmentation but also chemical pollution. Kibale National Park (Uganda), Sebitoli forest, surrounded by tea and crop fields, is the home range of chimpanzees presenting congenital facial dysplasia. This study aimed to identify to what extent the same phenotypical features are observed in baboons (Papio anubis) of this area.

Methods: A total of 25,390 clips recorded by 14 camera traps between January 2017 and April $42 \quad 2018$ were analyzed.

43 Results: We identified 30 immature and adult baboons of both sexes with nose and lip deformities. They were more frequently observed in the North-Western part of the area. Conclusions: A possible effect of pesticides used in crops at the border of their habitat is suspected to alter the embryonic development. This study emphasizes the importance of noninvasive methods to detect health problems in wild primates that can act as sentinels for human health.

49

50 Key words: malformation, primate, camera-trap, endocrine disruptor, anthropogenic pressure 


\section{Introduction}

Most primate species are threatened with extinction or declining populations resulting from escalating and unsustainable human activities ${ }^{1}$. These activities lead to anthropogenic environmental modifications that could affect wild primates by cascading effects. Non-human primates can act as sentinels of environmental toxics caused by anthropogenic activities. However, exposure to pollution is rarely measured and cases of intoxication rarely reported. Accumulation of heavy metals and levels of lead were measured in different locations and species such as howler monkeys (Alouatta pigra) ${ }^{2}$, in urban free-ranging rhesus monkey (Macaca mulatta $)^{3}$ and in long-tailed monkeys (Macaca fascicularis) ${ }^{4}$. Levels of serum dioxin were measured on douc langurs (Pygathrix nigripes) ${ }^{5,6}$ in Vietnam to understand the consequences of the use of Agent Orange during the war. However, no consequence on the health was observed associated to the levels of lead and dioxin in these studies.

The leading causes of primate extinction i.e. habitat $\operatorname{loss}^{1}$ are mainly due to the conversion of natural forests into agricultural systems. Environmental pollution due to conventional agricultural practices and use of pesticides could directly threaten the health of the surrounding wildlife ${ }^{7}$. Yet few surveys have been conducted to show evidence of exposure to pollutants on animal health due to close proximity to agricultural areas (birds studies ${ }^{8-10}$ but no primates). The direct or indirect observation of primates is a way to assess their health by looking at potential wounds or malformations. Most primates' deformities described in literature are the result of falls, fights, or wounding by predators ${ }^{11}$; and some are the collateral consequences of being caught in snares set by poachers ${ }^{12}$. However, in Sebitoli area in the northern part of Kibale National Park, Uganda, it has been suggested that the malformations observed have different causes. Indeed, exposition to chemicals used on crops, arboricides such as Agent Orange and pollution from combustion exhaust gases from vehicles could be the cause of the high number of congenital malformations observed in the primates including 16 chimpanzees and six baboons (Papio anubis) ${ }^{12-15}$. While chimpanzees are monitored daily in this area, baboons are opportunistically seen and Krief et al. ${ }^{15}$ described facial deformities in six baboons captured in a one minute video by a single camera trap.

The objective of this survey was to expand spatially and temporally the camera trap network to confirm, better describe the lesions in baboons and evaluate the number, age and sex class of affected individuals sharing the habitat with Sebitoli chimpanzees. 


\section{Material and methods}

The study site was the Sebitoli area located at the extreme North part of the Kibale National Park, Western Uganda $\left(795 \mathrm{~km}^{2}, 0^{\circ} 13^{\prime}-0^{\circ} 41^{\prime} \mathrm{N}\right.$ and $\left.30^{\circ} 19^{\prime}-30^{\circ} 32^{\prime} \mathrm{E}^{16}\right)$. The chimpanzees, and more generally wildlife have been monitored since 2009 by the Sebitoli Chimpanzee Project. This Park is composed of a mid-altitude forest with high plant and animal diversity ${ }^{17}$. The Sebitoli area is surrounded by human activity, and in particular, agriculture comprising in the western fringes, small farms with food crops, tea and eucalyptus, and to the East, tea estates and eucalyptus plantations. Phytochemical use differs according to the crops and thus to the area $^{15}$. In order to understand if the location and the crop type in contact with the territory of a group of baboons could influence the number of affected individuals, we divided the Sebitoli area into four zones delimited by the tarmac road crossing the chimpanzee home range $\left(20 \mathrm{~km}^{2}\right)$ in the south ${ }^{18}$ and two survey transects that divided the region into equivalent areas in west, east, north and south (Figure 1). We assumed that East and West are differently affected by pesticides and that the road play a "natural" limits between groups of North and South. We counted the malformed individuals encountered in the video clips recorded by the cameras localized in each of the four zones to understand if malformed individuals frequent more often one of the four zones.

From January 2017 to April 2018, up to 14 camera traps (CT) equivalent to 4746 CT days were set in the forest (named hereafter "forest-CT") and in the border of cultivated fields of maize (named hereafter "garden-CT") that surround the Park (Figure 1). The locations are recorded with a GPS Garmin 64CS and projected on a map ${ }^{19}$. The recorded clips are collected every two weeks. We used 13 HD video-traps Reconyx XR-6 Ultrafire ${ }^{\mathrm{TM}}$ and 2 HD video-traps Bushnell Trophy Cam HD Max ${ }^{\mathrm{TM}}$ with a day/night auto sensor and sound recordings. The settings were: high definition video of $1280 \times 720$ pixels, video length of $30 \mathrm{~s}$ for Reconyx ${ }^{\mathrm{TM}}$ and $60 \mathrm{~s}$ for Bushnell ${ }^{\mathrm{TM}}$. Video recording started when motion was sensed at a distance of up to $21 \mathrm{~m}$ for Recony $\mathrm{x}^{\mathrm{TM}}$ and $18 \mathrm{~m}$ for Bushnell ${ }^{\mathrm{TM}}$; there is a $5 \mathrm{~s}$ delay between consecutive triggers. Camera traps were set at least $1 \mathrm{~m}$ above the ground and at least $1 \mathrm{~m}$ off the trail or on an animal track where we expected the animals to pass. Three CT were set and active at the same location during the entire duration of this study. Other CT were moved in the forest according to (1) presence of mature crops at the edge of the forest in order to record crop feeding events by chimpanzees, baboons and elephants or (2) presence of bees nests visited by chimpanzees in order to obtain footage of tools used for honey harvesting by chimpanzees (3) different events 
such as stealing and breaking of CT by animals or poachers resulting of some CT being not active during some periods.

119
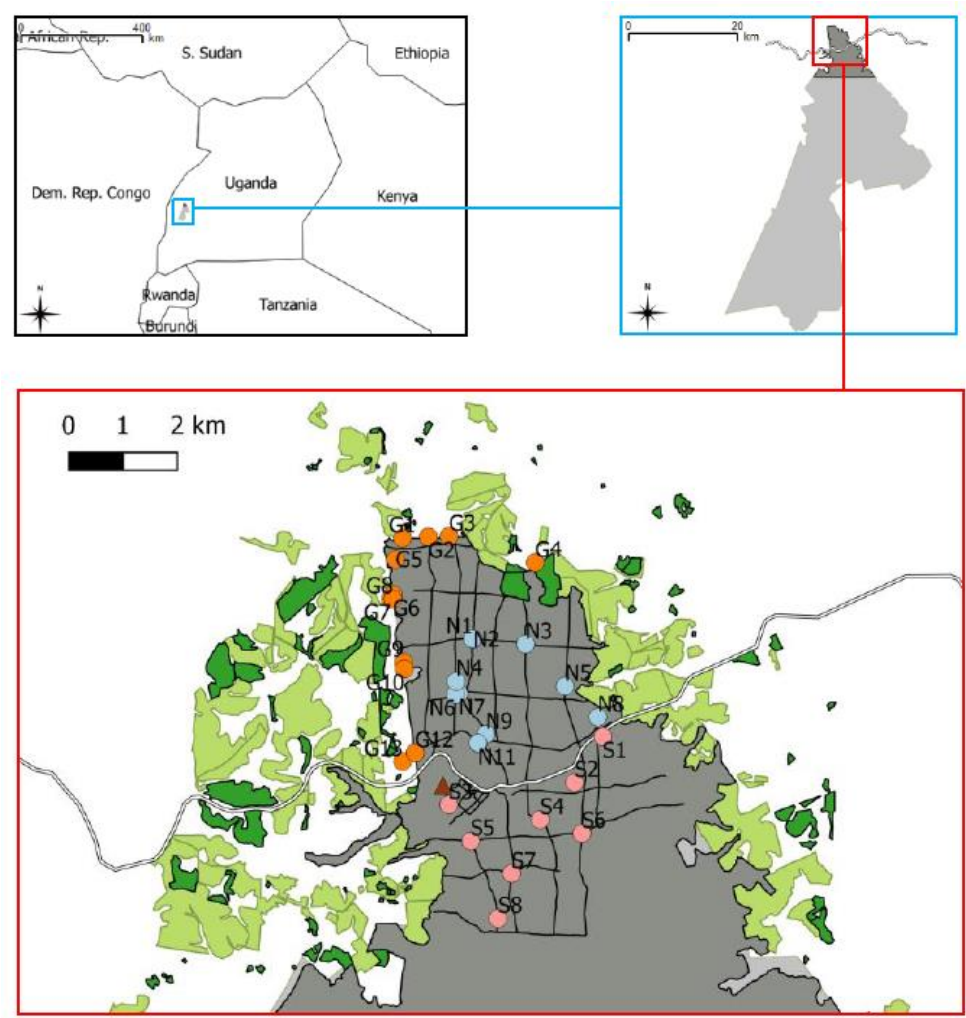

LEGEND

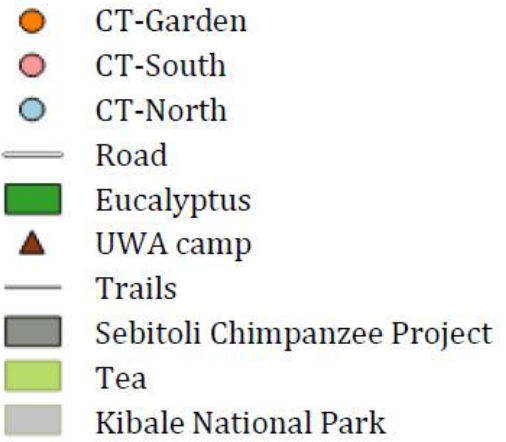

Figure 1. Map of the camera-trap study in the Sebitoli Chimpanzee Project, Kibale National Park in Uganda. We placed 13 camera-traps in the garden (CT-Garden), 19 camera-traps in the forest: 11 in the Northern part (CTNorth) and 8 in the Southern part (CT-South) of the road that cross the area. The forest is surrounded by eucalyptus and tea plantations.

For each clip we identified the animal species observed, the number of individuals of each species seen, their activities and the health impairments observed. When successive clips started less than 5 minutes apart with the same species being present, we considered them not to be independent and thus animals were considered to be part of the same group. If it was more than 5 min and less than 10 minutes between the clips and we could identify again clearly an individual previously identified (known or because of some features) we also considered those clips as non-independent. For those non-independent clips, we counted the number of individuals that appear for the first time in the given clip and were not seen in the previous clip. By adding the number of individuals that appeared to be different, we could estimate the size of the group. We calculated the relative abundance of the presence of baboons by dividing the number of individuals seen (could be the same individuals over the month) by $100 \mathrm{CT}$ days. 
The CT days are the days for which the camera was fully operational and could register. It excludes events of CT's stealing and memory card full in few days because of vegetation movement in front of the High Sensitivity Image sensor.

We tried as far as possible to determine the sex and the class of age (adapted from Packer ${ }^{20}$; Rose $^{21}$ ) for the olive baboons: infant ( 0 to 1 year, carried by mother), juvenile ( 1 to 4 years, small and not carried by mother) and mature (i.e., sexually mature individual including adult and sub-adult more than 4 years). The class of age of an individual reported corresponds to its first observation during the study period. Sex determination of juveniles and infants from camera trap videos was often difficult; therefore, this age category is generally classed as unknown sex. When individuals looked very similar and cannot be morphologically differentiated, we assumed that they were the same individual seen on different occasions. We defined mother-infant pair when an infant has been seen carried by its mother.

For individuals with physical features related to health impairment, we extracted a screen shot from the video-clip and described them as precisely as possible. We classified the abnormalities related to fur color (depigmentation), malformation or wound (presence of blood, pus or scab). We specified the body part affected: the head, the limbs, the trunk, the tail or the genitals. For facial malformations, parts of the face affected are mentioned as followed: nasal bone, nostrils, lip, ectopic apertures on the nasal bone and others features.

The baboons were observed without resorting to invasive methods and without interaction with the researchers. We adhered to the research protocols defined by the guidelines of the Uganda Wildlife Authority (UWA), which were also approved by the Muséum national d'Histoire naturelle (Memorandum of Understanding MNHN/UWA/Makerere University SJ 445-12).

\section{Results}

Out of 34 species identified, olive baboons were observed on 3,238 clips out of 25,390 clips recorded in 4,746 days by 14 cameras over an area covering about $20 \mathrm{~km}^{2}$. We saw 4,906 baboons over 2,204 clips in the forest-CT clips (abundance relative per $100 \mathrm{CT}$-days $=118.8$ ) against 1,645 baboons over 1,034 clips in the garden-CT clips (abundance relative per $100 \mathrm{CT}$ days $=266.2$ ). 
Table 1. Individuals observed with particularities classed by the localization and the type of the particularity.

\begin{tabular}{l|cccccc} 
Localization & Face & Limbs & Trunk & Tail & Genital & Total \\
\hline Depigmentation & 1 & - & - & - & - & 1 \\
Malformation & 30 & 1 & 1 & - & - & 32 \\
Malformation/wound & - & - & - & 6 & - & 6 \\
Wound & 4 & 7 & 2 & 1 & 1 & 15 \\
Total & 35 & 8 & 3 & 7 & 1 & 54
\end{tabular}

Out of the 6551 occurrences when a baboon can be seen, we identified 54 different individuals affected by physical defects (Table 1). Among them, 30 individuals were displaying facial dysplasia: 25 had malformed nostrils, 12 had ectopic apertures on the nose, 10 had an interruption of the nasal bone and three had others defects. The detailed description of the individuals presenting facials deformities is available in Table 2 as well as a screen capture of the face for each of them. Each individual was seen a mean of 2.8 times ranging from 1 to 14 times in 12 different locations (seven in the forest and five in the garden) over 33 CT locations during the entire study period. None of the individuals with facial dysplasia had wounds or infections. The lesions observed at different occasions did not change: they did not increase or decrease in size or severity. Most of the individuals with facial deformities were mature baboons $(n=20)$ with nine males, eight females and three of unknown sex. We observed nine juveniles and one infant carried by a non-malformed mother. For two adult females affected (Ind $2 \&$ Ind 3), we could properly observe their infants who did not have visible malformations. The females weremostly affected at the nostrils $(n=7)$, the nasal bone $(n=3)$ and by having ectopic apertures $(n=2)$. The males had also mostly malformed nostrils $(n=8)$, but ectopic apertures $(n=7)$ were more frequent than nasal bone deformity $(n=3)$. There is no apparent effect of gender.

Sixteen individuals ( 8 adult males, 3 adult females, 1 adult unknown sex and 4 immature unknown sexes) were seen in association on 17 times in non-independent clips (Table 3). The troops of baboons were not habituated and clearly identified in this study but those associations of recognizable baboons allowed us to establish a draft of troops. We identified a possible troop that included those sixteen individuals only visible in five locations of CT in the North. 
Table 2. Listed individuals with facial malformations with the picture taken from a screen capture of a video clip.

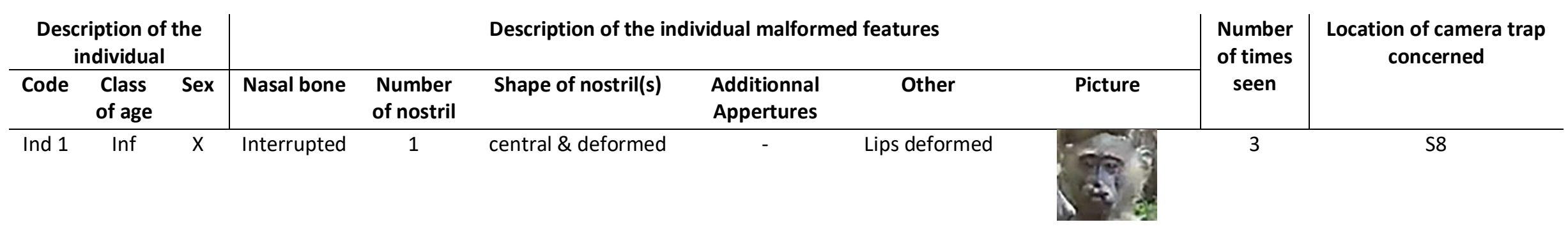

\begin{tabular}{|c|c|c|c|c|c|c|c|c|c|c|}
\hline Ind 2 & Ad & $\mathrm{F}$ & Interrupted & 1 & central \& round & Bottom left & - & & 12 & N4, N5, N6, G3, G9, G11 \\
\hline Ind 3 & Ad & $\mathrm{F}$ & Interrupted & 1 & central \& triangular & - & - & $\%$ & 14 & $\begin{array}{c}\text { N4, N6, G2, G8, G9, G11, } \\
\text { G10 }\end{array}$ \\
\hline Ind 4 & Juv & $x$ & Interrupted & 2 & $\begin{array}{c}\text { asymmetric (left } \\
\text { larger) }\end{array}$ & - & Lips twisted & & 1 & S8 \\
\hline Ind 5 & Juv & $x$ & - & 1 & central \& triangular & - & - & & 3 & S1, N4, N8 \\
\hline Ind 6 & Ad & M & Interrupted & 2 & - & $\begin{array}{l}\text { Bottom } \\
\text { central }\end{array}$ & - & & 1 & N6 \\
\hline
\end{tabular}


Table 2. (Continued)

\begin{tabular}{|c|c|c|c|c|c|c|c|c|c|c|}
\hline \multicolumn{3}{|c|}{$\begin{array}{l}\text { Description of the } \\
\text { individual }\end{array}$} & \multicolumn{6}{|c|}{ Description of the individual malformed features } & \multirow{2}{*}{$\begin{array}{c}\text { Number } \\
\text { of times } \\
\text { seen }\end{array}$} & \multirow[t]{2}{*}{$\begin{array}{c}\text { Location of camera trap } \\
\text { concerned }\end{array}$} \\
\hline Code & $\begin{array}{l}\text { Class } \\
\text { of age }\end{array}$ & Sex & Nasal bone & $\begin{array}{l}\text { Number } \\
\text { of nostril }\end{array}$ & Shape of nostril(s) & $\begin{array}{l}\text { Additionnal } \\
\text { Appertures }\end{array}$ & Other & Picture & & \\
\hline Ind 7 & $\mathrm{Ad}$ & M & - & 2 & $\begin{array}{c}\text { asymmetric (right } \\
\text { larger) }\end{array}$ & $\begin{array}{l}\text { Slit in the } \\
\text { middle of the } \\
\text { nose }\end{array}$ & - & & 6 & N4, N6, S8 \\
\hline Ind 8 & $\mathrm{Ad}$ & $\mathrm{F}$ & - & 1 & central \& round & - & - & & 1 & S8 \\
\hline Ind 9 & Juv & $x$ & - & 2 & - & - & $\begin{array}{l}\text { Asymmetric } \\
\text { frown }\end{array}$ & & 6 & N4, N6, G2, G9 \\
\hline $\begin{array}{l}\text { Ind } \\
10\end{array}$ & $\mathrm{Ad}$ & M & - & 2 & $\begin{array}{l}\text { asymmetric (left } \\
\text { larger) }\end{array}$ & $\begin{array}{l}\text { Slit in the } \\
\text { middle of the } \\
\text { nose }\end{array}$ & - & & 5 & N4, N6, G2, G9 \\
\hline $\begin{array}{l}\text { Ind } \\
11\end{array}$ & Juv & $x$ & - & 1 & central \& round & - & - & & 5 & N4, N6, S2 \\
\hline $\begin{array}{l}\text { Ind } \\
12\end{array}$ & Juv & $x$ & - & 1 & central \& deformed & - & - & & 2 & $\mathrm{~N} 4, \mathrm{G} 2$ \\
\hline
\end{tabular}


Table 2. (Continued)

\begin{tabular}{|c|c|c|c|c|c|c|c|c|c|c|}
\hline \multicolumn{3}{|c|}{$\begin{array}{l}\text { Description of the } \\
\text { individual }\end{array}$} & \multicolumn{6}{|c|}{ Description of the individual malformed features } & \multirow{2}{*}{$\begin{array}{l}\text { Number } \\
\text { of times } \\
\text { seen }\end{array}$} & \multirow[t]{2}{*}{$\begin{array}{l}\text { Location of camera trap } \\
\text { concerned }\end{array}$} \\
\hline Code & $\begin{array}{l}\text { Class } \\
\text { of age }\end{array}$ & Sex & Nasal bone & $\begin{array}{l}\text { Number } \\
\text { of nostril }\end{array}$ & Shape of nostril(s) & $\begin{array}{l}\text { Additionnal } \\
\text { Appertures }\end{array}$ & Other & Picture & & \\
\hline $\begin{array}{l}\text { Ind } \\
13\end{array}$ & Ad & $\mathrm{F}$ & - & 2 & $\begin{array}{c}\text { narrow and } \\
\text { asymmetric (left } \\
\text { higher) }\end{array}$ & - & - & & 2 & N4 \\
\hline $\begin{array}{l}\text { Ind } \\
14\end{array}$ & Ad & M & Interrupted & 2 & - & Bottom & - & & 1 & N6 \\
\hline $\begin{array}{l}\text { Ind } \\
15\end{array}$ & Juv & $\mathrm{x}$ & - & 1 & no nasal septum & - & - & & 1 & N4 \\
\hline $\begin{array}{l}\text { Ind } \\
16\end{array}$ & Ad & M & Interrupted & 2 & - & $\begin{array}{l}\text { Bottom } \\
\text { central }\end{array}$ & - & & 2 & N4 \\
\hline $\begin{array}{l}\text { Ind } \\
17\end{array}$ & $\mathrm{Ad}$ & $\mathrm{M}$ & - & 1 & no nasal septum & - & - & & 2 & N4, G2 \\
\hline $\begin{array}{l}\text { Ind } \\
18\end{array}$ & $\mathrm{Ad}$ & $\mathrm{M}$ & - & 2 & $\begin{array}{l}\text { asymmetry (right } \\
\text { larger) }\end{array}$ & $\begin{array}{l}\text { Slit in the left } \\
\text { side of the } \\
\text { nose }\end{array}$ & - & & 2 & N4, N6 \\
\hline
\end{tabular}


Table 2. (Continued)

\begin{tabular}{|c|c|c|c|c|c|c|c|c|c|c|}
\hline \multicolumn{3}{|c|}{$\begin{array}{l}\text { Description of the } \\
\text { individual }\end{array}$} & \multicolumn{6}{|c|}{ Description of the individual malformed features } & \multirow{2}{*}{$\begin{array}{l}\text { Number } \\
\text { of times } \\
\text { seen }\end{array}$} & \multirow[t]{2}{*}{$\begin{array}{l}\text { Location of camera trap } \\
\text { concerned }\end{array}$} \\
\hline Code & $\begin{array}{l}\text { Class } \\
\text { of age }\end{array}$ & Sex & Nasal bone & $\begin{array}{l}\text { Number } \\
\text { of nostril }\end{array}$ & Shape of nostril(s) & $\begin{array}{l}\text { Additionnal } \\
\text { Appertures }\end{array}$ & Other & Picture & & \\
\hline $\begin{array}{c}\text { Ind } \\
19\end{array}$ & Ad & $\mathrm{M}$ & Pleated & 2 & $\begin{array}{c}\text { narrow and } \\
\text { asymmetric (left } \\
\text { longer) }\end{array}$ & - & - & & 1 & N5 \\
\hline $\begin{array}{l}\text { Ind } \\
20\end{array}$ & Ad & M & - & 2 & $\begin{array}{l}\text { asymmetry (left } \\
\text { larger and higher) }\end{array}$ & - & - & & 3 & N8 \\
\hline $\begin{array}{l}\text { Ind } \\
21\end{array}$ & $\mathrm{Ad}$ & M & - & 1 & no nasal septum & $\begin{array}{l}\text { In the top } \\
\text { middle of the } \\
\text { two nostrils }\end{array}$ & - & & 2 & N8, S2 \\
\hline $\begin{array}{l}\text { Ind } \\
22\end{array}$ & Ad & M & - & 2 & flat nose & - & - & & 1 & $\mathrm{G} 2$ \\
\hline $\begin{array}{l}\text { Ind } \\
23\end{array}$ & Juv & $x$ & Interrupted & 2 & - & $\begin{array}{l}\text { Slit on top of } \\
\text { the nose }\end{array}$ & - & & 1 & $\mathrm{G} 2$ \\
\hline $\begin{array}{c}\text { Ind } \\
24\end{array}$ & Ad & $x$ & - & 2 & flat nose & - & - & & 1 & G9 \\
\hline
\end{tabular}


Table 2. (Continued)

\begin{tabular}{|c|c|c|c|c|c|c|c|c|c|c|}
\hline \multicolumn{3}{|c|}{$\begin{array}{l}\text { Description of the } \\
\text { individual }\end{array}$} & \multicolumn{6}{|c|}{ Description of the individual malformed features } & \multirow{2}{*}{$\begin{array}{c}\text { Number } \\
\text { of times } \\
\text { seen }\end{array}$} & \multirow[t]{2}{*}{$\begin{array}{l}\text { Location of camera trap } \\
\text { concerned }\end{array}$} \\
\hline Code & $\begin{array}{l}\text { Class } \\
\text { of age }\end{array}$ & Sex & Nasal bone & $\begin{array}{l}\text { Number } \\
\text { of nostril }\end{array}$ & Shape of nostril(s) & $\begin{array}{l}\text { Additionnal } \\
\text { Appertures }\end{array}$ & Other & Picture & & \\
\hline $\begin{array}{l}\text { Ind } \\
25\end{array}$ & $\mathrm{Ad}$ & $\mathrm{F}$ & - & 2 & $\begin{array}{l}\text { asymmetry (left } \\
\text { higher) }\end{array}$ & $\begin{array}{l}\text { Slit in the left } \\
\text { side of the } \\
\text { nose }\end{array}$ & - & & 1 & N8 \\
\hline $\begin{array}{l}\text { Ind } \\
26\end{array}$ & Juv & $\mathrm{x}$ & - & 1 & central \& round & $\begin{array}{l}\text { Slits under the } \\
\text { nose }\end{array}$ & - & & 1 & G9 \\
\hline $\begin{array}{l}\text { Ind } \\
27\end{array}$ & $\mathrm{Ad}$ & $\mathrm{F}$ & - & 2 & $\begin{array}{l}\text { twisted on the right } \\
\text { side }\end{array}$ & - & - & & 2 & G9, N6 \\
\hline $\begin{array}{l}\text { Ind } \\
28\end{array}$ & $\mathrm{Ad}$ & $\mathrm{F}$ & Interrupted & 1 & central \& triangular & - & - & & 1 & G9 \\
\hline $\begin{array}{l}\text { Ind } \\
29\end{array}$ & $\mathrm{Ad}$ & $x$ & - & 2 & $\begin{array}{l}\text { flat nose and } \\
\text { asymmetric (left } \\
\text { larger) }\end{array}$ & - & - & & 1 & G11 \\
\hline $\begin{array}{l}\text { Ind } \\
30\end{array}$ & $\mathrm{Ad}$ & $x$ & - & 1 & central \& round & $\begin{array}{l}\text { Slit on top of } \\
\text { the nose }\end{array}$ & - & & 1 & G11 \\
\hline
\end{tabular}


Table 3. Association of individuals with facial malformations observed in non-independent clips.

\begin{tabular}{|c|c|c|}
\hline Individuals together & Group size & Where \\
\hline Ind $2 \&$ Ind $3 \&$ Ind $5 \&$ Ind $10 \&$ Ind 15 & 29 & N4 \\
\hline Ind 2 \& Ind 3 & 13 & N6 \\
\hline Ind 2 \& Ind 3 & 18 & G9 \\
\hline Ind 2 \& Ind 3 & 20 & N6 \\
\hline Ind 2 \& Ind 13 & 4 & N4 \\
\hline Ind 2 \& Ind 14 & 22 & N6 \\
\hline Ind 2 \& Ind 18 & 20 & N6 \\
\hline Ind 3 \& Ind 7 & 25 & N4 \\
\hline Ind 3 \& Ind 23 & 43 & $\mathrm{G} 2$ \\
\hline Ind 3 \& Ind 24 & 8 & G9 \\
\hline Ind 5 \& Ind 21 & 58 & N8 \\
\hline Ind $7 \&$ Ind 9 & 32 & N4 \\
\hline Ind 9 \& Ind 10 & 21 & N6 \\
\hline Ind 9 \& Ind 11 & 25 & N6 \\
\hline Ind $11 \&$ Ind $13 \&$ Ind $16 \&$ Ind 17 & 24 & N4 \\
\hline Ind $16 \&$ Ind 18 & 23 & N4 \\
\hline
\end{tabular}

202

Individuals with facial defects are relatively more abundant in the two zones in North and more precisely the North-Western area of Sebitoli (Table 4).

Table 4. Distribution in Sebitoli of malformed individuals.

\begin{tabular}{|c|cccc} 
Position & Number of individuals seen & Number of ct & Number of days filmed & Abundance \\
\hline N/W & 23 & 21 & 1406 & 1,63584637 \\
N/E & 6 & 4 & 804 & 0,74626866 \\
S/W & 3 & 4 & 1085 & 0,2764977 \\
S/E & 5 & 4 & 833 & 0,6002401
\end{tabular}

Note: Abundance $=$ Number of individuals seen $/ 100$ CT-days

\section{Discussion}

Facial deformities affected 30 olive baboons of both sexes and all the classes of age in Sebitoli, confirming the opportunistic footage by camera trap in 2014 of six olive baboons presenting facial malformations in a troop of 35 individuals ${ }^{15}$. There were no wounds, pus or blood likely excluding infection by Treponema pallidum ${ }^{22}$. For individuals seen several times, there was no evolution of the lesions during the study period, and the naso-oro-facial defects are observed in 
very young individuals suggesting congenital origins of those malformations. The baboons appeared otherwise to be healthy, integrated into social groups, and apparently reproducing as two females with dysplasia were carrying non-malformed infants. Malformations also occured in other parts of the body as an infant had severely malformed limbs causing locomotor issue and an adult male had a hunchback but those could be related to malnutrition or trauma. Spontaneous malformations occur in a variety of non -human primates in captivity but at low rate (0.3\%-0.9\%) (Papio sp..$^{23,24} ;$ Macaca sp. ${ }^{24,25}$; ). Clefts of the palate and/or of the upper lip are very rare in wild non-human primates but have been observed in several species in captivity includingStrepsirrhines (Varecia variegata ${ }^{26}$ ) as well as in Haplorhines, including New World monkeys (Callithrix jacchus ${ }^{27}$; Saimiri sp. ${ }^{28,29}$ ), Old World monkeys (Macaca sp. ${ }^{30,31}$; Papio $s p .{ }^{32}$; Mandrillus sphyn $x^{33}$ ), and great apes (Gorilla $s p .{ }^{34}$ ). In Sebitoli, the large number of individuals of all age and sex classes with facial defects $(n=30)$ observed in the relatively small area studied $\left(20 \mathrm{~km}^{2}\right)$, the absence of other cases reported in the national park covering $795 \mathrm{~km}^{2}$ likely indicate an etiology related to a local cause. Olive baboons usually live in multi-male, multi-female groups or "troops", ranging in size from 15 to 150 individuals ${ }^{35-37}$. In adjacent troops of olive baboons, all males emigrated from their natal troop in order to mate after they reach sexual maturity and can return for short period of time ${ }^{20,38-40}$ whereas nearly all females remained in their natal troop ${ }^{41}$ making the females the basis of troop identity. One-male groups also exist and can be the majority encountered ${ }^{42}$. The home range of forest olive baboons has been rarely studied and was estimated at roughly 390 ha and $520 \mathrm{ha}^{35}$ which is small compared to the average home range of 3,890 ha given by DeVore ${ }^{43}$ for savannah baboons. The five locations of CT where we had seen the sixteen individuals in association represented an area of 522 ha, so we can estimate that they are part of the same larger troop. Thus, in a single group estimated to count 58 individuals, one out of four individuals is affected.

Only one other case of facial deformity concerning an olive baboon has been documented in the south of the park where a female was missing the most basal part of the upper jaw and nose $^{45}$. In addition, there are no cases of similar lesions described in areas without exposition to agrochemicals. This indicates that pesticide exposure could contribute to the facial dysplasia observed in olive baboons as it was suspected for chimpanzees ${ }^{12,13,15}$. The fact that the two primate species -chimpanzees and olive baboons- in exactly the same range suffer from the same deformities strengthens the chemical pollution hypothesis. In addition, both species regularly feed on crops ${ }^{46,47}$. In this study area, the crop fields are mostly in the North-western part, between 2 and $4 \mathrm{~km}$ away from the road. The most abundant proportion of malformed 
individuals was also found in the north-western patches suggesting that the chemicals on food cropsassociated with those sprayed on tea, could be indeed responsible. The most affected troop of baboons is living in the Northern location where they are not exposed to road pollution. This is in favor of an etiology related to pesticides rather than combustion gas exposition. According to previous analyses, maize used in this area and consumed by this troop was coated with imidacloprid $^{15}$. In addition, maize stem and maize seed samples from Nyakabingo and Kyawankada, the two locations at the far north of the study area, were tested positive for chlorpyrifos $^{15}$. In these two locations, farmers also reported using 2,4 D amine on maize. Glyphosate is used in every tea estate including the one in Eastern part of the home range ${ }^{15}$. The fact that affected baboons are more often observed in the Western part than Eastern part of the range seems to support an effect of pesticides used in maize or glyphosate associated with other chemicals rather than an effect attributed to glyphosate alone. It is the possible unique combination of pesticides, fungicides, herbicides, and fertilizers used in those food crops that could have contaminated water, soil and plants and in consequence affected the wildlife of the $\operatorname{park}^{13}$.

In response to crop-raiding, farmers usually chased primates, probably causing the baboons of this area to fear human contact. They tend to rapidly flee when humans are near ${ }^{48}$ making them difficult to observe, individually identify, and study. The use of camera traps is very convenient to overcome this difficulty ${ }^{49}$. It is an important tool that allows studying primates without exacerbating potential threats to the species like the transmission of zoonotic diseases ${ }^{50-52}$, and the potential exposure to poachers ${ }^{53}$. While also mitigating the negative impacts of habituation, the use of camera-traps can overcome the limitations of direct observations by filming in accessible $\operatorname{areas}^{54,55}$ and rare or elusive individuals without the potential human presence bias $^{56,57}$; in a relatively short period of time ${ }^{49}$ However the counting of individuals in a group, the individual health and behavioral monitoring to estimate the effect of the phenotypical defects would be necessary; there are impossible with this type of indirect survey. Technological advances have led to widespread adoption of camera traps to survey wildlife distribution, abundance and behavior ${ }^{58,59}$ and recently health ${ }^{15}$. Indeed, an opportunistic footage by camera trap in 2014 had raised the issue of capturing facial malformations by camera trap with six olive baboons in Sebitoli ${ }^{15}$. Our study on a larger scale confirmed the interest of using camera-traps to survey the health of wildlife and improve our knowledge about the insidious threat of pollution. 


\section{Acknowledgement}

We are grateful to the Uganda Wildlife Authority, Uganda National Council for Science and Technology for permission to conduct research at Sebitoli. The Great Ape Conservation Project, the Fondation Ensemble, the Fondation pour la Nature et l'Homme, the Fondation Prince Albert II provided financial support for the research conducted at Sebitoli. We deeply thank JeanMichel Krief, co-director of Great Ape Conservation Project, the field assistants of the Sebitoli Chimpanzee Project Emmanuel Balinda, Deogratius Kiomuhangi, Joseph Alinaitwe, Ibrahim Nyakana, Wilson Muzahura, Edward Kalyegira, Nelson Tegume and Nelson Fawoh, the SCP coordinator, Robert Asyimwe, Robert Nyakahuma and Daniela Birungi. We thank Sarah Bortolamiol for her collaboration to organize spatial data.

\section{References}

1. Estrada A, Garber PA, Rylands AB, Roos C, Fernandez-Duque E, Di Fiore A, Rovero F. Impending extinction crisis of the world's primates: Why primates matter. Sci $A d v$ 2017;3(1):e1600946.

2. Serio-Silva JC, Olguín EJ, Garcia-Feria L, Tapia-Fierro K, Chapman CA. Cascading impacts of anthropogenically driven habitat loss: deforestation, flooding, and possible lead poisoning in howler monkeys (Alouatta pigra). Primates 2015;56(1):29-35.

3. Engel G, O'Hara TM, Cardona-Marek T, Heidrich J, Chalise MK, Kyes R, Jones-Engel L. Synanthropic primates in Asia: potential sentinels for environmental toxins. Am J Phys Anthropol 2010;142(3):453-460.

4. Schillaci MA, Lee BPY, Castellini JM, Reid MJ, O'Hara TM. Lead levels in long-tailed macaque (Macaca fascicularis) hair from Singapore. Primates 2011;52(2):163-170.

5. Brockman DK, Harrison RO, Nadler T. Conservation of douc langurs in Vietnam: An assessment of Agent Orange exposure in douc langurs (Pygathrix) at the Endangered Primate Rescue Center, Cuc Phuong National Park, Vietnam. Vi J Primatol 2009;1(3).

6. Brockman DK, Harrison RO. Agent orange exposure in black-shanked douc langurs (Pygathrix nigripes) at Nam Cat Tien National Park, Vi J Primatol 2013;2(2):49-64. 
7. Lamarque F, Hatier C, Artois M, Berny P, Diedler C. Le réseau SAGIR, réseau national de suivi sanitaire de la faune sauvage française. Epidémiologie et santé animale, 2000;37:21-30.

8. Bro E, Millot F, Decors A, Devillers J. Quantification of potential exposure of gray partridge (Perdix perdix) to pesticide active substances in farmlands. Sci Total Environ 2015;52:315-325.

9. Ciliberti A, Berny P, Delignette-Muller ML, de Buffrénil V. The Nile monitor (Varanus niloticus; Squamata: Varanidae) as a sentinel species for lead and cadmium contamination in sub-Saharan wetlands. Sci Total Environ 2011;409(22):4735-4745.

10. Millot F, Berny P, Decors A, Bro E. Little field evidence of direct acute and short-term effects of current pesticides on the grey partridge. Ecotoxicol Environ Saf 2015;117:41-61.

11. Crockett CM, Pope T. Inferring patterns of aggression from red howler monkey injuries. Am J Primatol 1998;15(4):289-308.

12. Krief S, Cibot M, Bortolamiol S, Seguya A, Krief JM, Masi S. Wild chimpanzees on the edge: nocturnal activities in croplands. PLoS One, 2014;9(10):e109925.

13. Krief S, Krief JM, Seguya A, Couly G, Levi G. Facial dysplasia in wild chimpanzees. $J$ Med Primatol 2014;43(4):280-283.

\section{Krief S, Watts DP, Mitani JC, Krief JM, Cibot M, Bortolamiol S, ... Couly G. Two cases} of cleft lip and other congenital anomalies in wild chimpanzees living in Kibale National Park, Uganda. Cleft Palate Craniofac J 2015;52(6):743-750.

15. Krief S, Berny P, Gumisiriza F, Gross R, Demeneix B, Fini JB, ... Wasswa J. Agricultural expansion as risk to endangered wildlife: Pesticide exposure in wild chimpanzees and baboons displaying facial dysplasia. Sci Total Environ 2017;598:647-656.

16. Chapman CA, Lambert JE. Habitat alteration and the conservation of African primates: case study of Kibale National Park, Uganda. Am J Primatol 2000;50(3):169-185.

17. Treves A, Mwima P, Plumptre AJ, Isoke S. Camera-trapping forest-woodland wildlife of western Uganda reveals how gregariousness biases estimates of relative abundance and distribution. Biol Conserv 2010;143(2):521-528. 
18. Cibot M, Bortolamiol S, Seguya A, Krief S. Chimpanzees facing a dangerous situation: a high-traffic asphalted road in the sebitoli area of kibale national park, Uganda. Am J Primatol 2015;77(8):890-900.

19. Bortolamiol S, Cohen M, Potts K, Pennec F, Rwaburindore P, Kasenene J, ... Krief S. Suitable habitats for endangered frugivorous mammals: small-scale comparison, regeneration forest and chimpanzee density in Kibale National Park, Uganda. PloS one 2014;9(7):e102177.

20. Packer C. Inter-troop transfer and inbreeding avoidance in Papio anubis. Anim Behav 1979;27:1-36.

21. Rose MD.Positional behaviour of olive baboons (Papio anubis) and its relationship to maintenance and social activities. Primates 1977;18(1):59-116.

22. Harper KN, Fyumagwa RD, Hoare R, Wambura PN, Coppenhaver DH, Sapolsky RM, ... Batamuzi EK. Treponema pallidum infection in the wild baboons of East Africa: distribution and genetic characterization of the strains responsible. PLoS One 2012;7(12):e50882.

23. Hendrickx AG, Axelrod, LR, Clayborn LD. 'Thalidomide'syndrome in baboons. Nature 1966;210(5039):958.

24. Wilson JG, Gavan JA. Congenital malformations in nonhuman primates: spontaneous and experimentally induced. Anat Rec 1967;158(1):99-109.

25. Peterson PE, Short JJ, Tarara R, Valverde C, Rothgarn E, Hendrickx AG. Frequency of spontaneous congenital defects in rhesus and cynomolgus macaques. J Med Primatol 1997;26(5):267-275.

26. Benirschke K, Kumamoto AT, Bogart MH. Congenital anomalies in Lemur variegatus. $J$ Med Primatol 1981;10:38-45

27. Pugsley SL. Congenital malformations in a common marmoset (Callithrix jacchus) similar to human 13-trisomy syndrome. Lab Anim 1985;19(2):123-124.

28. Hoopes CW, Jerome CP. Oral-facial clefts and associated malformations in the squirrel monkey (Saimiri sciureus). J Med Primatol 1987;16(3):203-209. 
29. Goldschmidt B, Lopes CA, Moura M, Nogueira DM, Gonçalves MA, Fasano DM, ... Marinho AM. Cleft lip and palate associated with other malformations in a neotropical primate (Saimiri ustus). J Am Assoc Lab Anim Sci 2010;49(3):357-360.

30. Swindler DR, Merrill OM. Spontaneous cleft lip and palate in a living nonhuman primate, Macaca mulatta. Am J Physic Anthropol, 1971;34(3):435-439.

31. Peterson PE, Short JJ, Tarara R, Valverde C, Rothgarn E, Hendrickx AG. Frequency of spontaneous congenital defects in rhesus and cynomolgus macaques. J Med Primatol 1997;26(5):267-275.

32. Fox B, Owston MA, Kumar S, Dick EJ. Congenital anomalies in the baboon (Papio spp.). J Med Primatol 2011;40(5):357-363.

33. Hill WCO, Pi JS. Notes on two anomalies in mandrills (Mandrillus sphinx Linn.). Folia Primatol 1970;12(4):290-295.

34. Siebert JR, Williams B, Collins D, Winkler LA, Swindler DR. Spontaneous cleft palate in a newborn gorilla (Gorilla gorilla gorilla). Cleft Palate Craniofac J 1998;35(5):436-441.

35. Rowell TE. Forest living baboons in Uganda. J Zool 1966;149(3):344-364.

36. Dunbar RIM, Dunbar EP. Ecological relations and niche separation between sympatric terrestrial primates in Ethiopia. Folia Primatol 1974;21(1):36-60.

37. Ray JC, Sapolsky RM. Styles of male social behavior and their endocrine correlates among high-ranking wild baboons. Am J Primatol 1992;28(4):231-250.

38. Smuts BB. Sex and friendship in baboons. New York: Aldine de Gruyter; 1985. 303 p.

39. Barton RA, Whiten A. Feeding competition among female olive baboons, Papio anubis. Anim Behav 1993;46(4):777-789.

40. Barton RA, Byrne RW, Whiten A. Ecology, feeding competition and social structure in baboons. Behav Ecol Sociobiol 1996;38(5):321-329.

41. Packer C. Male transfer in olive baboons. Nature 1975;255(5505):219. 
42. Kunz BK, Linsenmair KE. The disregarded West: diet and behavioural ecology of olive baboons in the Ivory Coast. Folia Primatol 2008;79(1):31-51.

43. DeVore I, Hall KRL. Baboon ecology. In Primate behavior: field studies of monkeys and apes. New York: Holt; 1965.

44. Butynski TM. Comparative Ecology of Blue Monkeys (Cercopithecus Mitis) in High-and Low-Density Subpopulations. Ecol Monogr 1990;60(1):1-26.

45. Struhsaker TT, Chapman CA, Pope TR, Marcus JR. Healthy baboon with no upper jaw or nose: an extreme case of adaptability in the Kibale National Park, Uganda. Primates 2011;52(1):15-18.

46. Naughton-Treves L. Predicting patterns of crop damage by wildlife around Kibale National Park, Uganda. Conserv Biol 1998;12(1):156-168.

47. Naughton-Treves L, Treves A, Chapman C, Wrangham R. Temporal patterns of cropraiding by primates: linking food availability in croplands and adjacent forest. $J$ Appl Ecol 1998;35(4):596-606.

48. Williamson EA, Feistner AT. Habituating primates: processes, techniques, variables and ethics. Field and laboratory methods in primatology: A practical guide; 2003. 25-39 p.

49. Boyer-Ontl KM, Pruetz JD. Giving the forest eyes: The benefits of using camera traps to study unhabituated chimpanzees (Pan troglodytes verus) in southeastern Senegal. Int J Primatol 2014;35(5):881-894.

50. Epstein JH, Price JT. The significant but understudied impact of pathogen transmission from humans to animals. Mt Sinai J Med 2009;76(5):448-455.

51. Köndgen S, Kühl H, N'goran PK, Walsh PD, Schenk S, Ernst N, ... Junglen, S. Pandemic human viruses cause decline of endangered great apes. Curr Biol 2008;18(4):260-264.

52. Woodford MH, Butynski TM, Karesh WB. Habituating the great apes: the disease risks. Oryx $2002 ; 36(2): 153-160$. 
414 53. Robbins MM, Boesch C. Among African apes: Stories and photos from the field. Univ of

415 California Press; 2011.

416 54. Kierulff MC, Santos GR, Canale GR, Guidorizzi CE, Cassano CR. The use of camera-

417 traps in a survey of the buff-headed capuchin monkey, Cebus xanthosternos. Neotrop

418 Primates 2004;12:56-59.

419

420 55. Tan CL, Yang Y, Niu K. Into the night: Camera traps reveal nocturnal activity in a

421 presumptive diurnal primate, Rhinopithecus brelichi. Primates 2013;54:1-6.

422

423 56. Bezerra BM, Bastos M, Souto A, Keasey MP, Eason P, Schiel N, Jones G. Camera trap

424 observations of nonhabituated critically endangered wild blonde capuchins, Sapajus flavius

425 (formerly Cebus flavius). Int J Primatol 2014;35.

426

427 57. Gerber BD, Williams PJ, Bailey LL. Primates and cameras: Noninvasive sampling to 428 make population-level inferences while accounting for imperfect detection. Int J Primatol $429 \quad 2014 ; 35$.

430

431

58. Rovero F, Zimmermann F, Berzi D, Meek P. "Which camera trap type and how many do I

432 need?" A review of camera features and study designs for a range of wildlife research

433 applications. Hystrix It J Mamm 2013;24(2):148-156.

434

59. Meek P, Fleming P, Ballard G, Banks P, Claridge A, Sanderson J, Swann D. Camera

436

Trapping: Wildlife Management and Research. CSIRO Publishing, Collingwood; 2014.

437 